Salix repens $\times S$. aurita $=S$. $\times$ ambigua Ehrh.

$S$. repens $\times S$. purpurea $=S . \times$ doniana $\mathrm{Sm}$.

$S$. repens $\times S$. viminalis $=S . \times$ friesiana Anderss.

$S$. alba $\times S$. pentandra ssp. angustifolia $=S . \times$ ehrhardtiana

$S$. caprea $\times S$. daphnoides $=S . \times$ erdingeri Kern. (rare!)

And there is an interesting intersectional hybrid between the Caprisalix and the Amerina group

$S$. triandra $\times S$. viminalis $=S . \times$ mollissima Ehrh. (=S. hippophaefolia Thuill.) 'Pure' species of willows at this place are to be found only in the $S$. repens-aggregate and the $S$. purpurea-aggregate.

The diversity of willows is matched by the diversity of the habitat: viz. the recently exposed terraces with clay soils of $\mathrm{pH}=8$ and cool spring areas, rich in orchids, with Pyrola, are nearly free of trees except for the willow hybrids. Close to it, eutrophic marshland, peat bogs, sand dunes, moist forests etc. provide habitats for a wide range of parent species for these hybrids. Apparently, the anthropogenic soils on the terraces are unsuitable for most willow species, but provide a 'test area' for various willow hybrids.

\title{
Possible postglacial introgressions in the Salix repens complex
}

\author{
Friedrich W.C. Mang
}

Am Knill 24, D-2000 Hamburg 73, Germany

The Salix repens aggregate is extremely variable: the growth forms include plants with creeping or even subterranean stems as well as shrubs up to $3 \mathrm{~m}$ high: the leaves may be glabrous and glanduliferous, or densely tomentose, and the number of nerves may vary between 5 and 17 (to 21); the catkins may be stalked or sessile; the style may be short, elongated or bifid; the capsules may be glabrous or tomentose.

Might it not be possible, that in the genus Salix, as in Betula, where these phenomena have been studied intensively, postglacial introgressions between the different subgroups have played an important role in its diversity?

The following species could be hypothesised as contributing certain characters into the Salix repens aggregate:

Salix herbacea L. - red capsules, bifid style

S. arbuscula L. - catkins with long stalks

S. livida Wahl. - long and narrow capsules, large stipules

S. bicolor Ehrh. - leaves with glands, leaves pale (glaucous) beneath, long linear stipules

S. lapponum L. - leaves tomentose, few lateral nerves

$S$. myrtilloides L. - glabrous and glaucous leaves with glands

Male and female clones of Salix 'arbuscula' found at Boberg near Hamburg suggest that they have originated from the Salix repens L. group by recombination within a complex which had formerly received Salix arbuscula characters by introgression. 